ANTONI SALM

\title{
„Nie dopuść, abyśmy ulegli pokusie” - od Pisma Świętego do codziennej liturgii i modlitwy
}

W wyniku odnowy biblijnej zmieniono polskitekst wezwania Modlitwy Pańskiej w Piśmie Świętym (Mt 6, 13 i Łk 11, 4) ,i nie wódź nas na pokuszenie” na „i nie dopuść, abyśmy ulegli pokusie”. Współczesna wersja, poprawna teologicznie i językowo, zadomowiła sięjuż w każdym wydaniu Biblii. Włączono ją nadto do lekcjonarza mszalnego, gdzie pojawia się kilka razy. Obecnie puka do drzwi modlitw codziennych, zarówno w Eucharystii, jak i w książeczkach do nabożeństwa. Przyczyny tego są ważkie, o czym starają się przekonać poniższe refleksje.

\section{Od „nie wódź” do „nie dopuść”}

Gdy w tej samej mszy świętej (np.we wtorek po Iniedzieli wielkiego postu) słyszymy w czytaniu Ewangelii: „, nie dopuść, abyśmy ulegli pokusie”, a wkrótce po tym „i nie wódź nas na pokuszenie” w obrzędach komunii świętej, zastanawiamy się, dlaczego te teksty się różnią. Sięgając do różnych edycji Pisma Świętego, np. do Biblii Tysiaclecia od wydania II (1971) do V (najnowszego, 2002), jak i do edycji pod redakcją Mariana Wolniewicza (tzw. Biblii Poznańskiej), poczynając od I wydania (1984), znajdujemy tam: „i nie dopuść, abyśmy ulegli pokusie” albo „i nie dozwól nam ulec pokusie”. Wersja ta ma zatem lat blisko 40, co oznaczałoby wiek dojrzały.

Historia i ocena poprzedniego sformułowania

Pisma biblijne nie zostały skomponowane w języku współczesnym. Zdanie: „nie wódź nas na pokuszenie” jest prośbą wypowiedzianą 
na sposób semicki ${ }^{1}$. W czasach biblijnych powszechne było przekonanie, że Bóg jest bezpośrednią przyczyną wszystkiego, co dzieje się na świe$\mathrm{cie}^{2}$, i zgodnie z tym sformułowano szóstą prośbę modlitwy Ojcze nasz.

Na podstawie rozważań filologicznych i teologicznych ks. Jan Drozd wyraził w swojej monografii przypuszczenie, że autor tłumaczenia Ewangelii św. Mateusza z języka hebrajskiego na język łaciński dokonanego w II wieku „nie rozumiał właściwego sensu tego zdania o składni na wskroś semickiej i przetłumaczył je dosłownie. Św. Hieronim przy rewizji przekładu starołacińskiego (Vetus Latina) nie poprawił tego zdania i w takim brzmieniu wprowadził je do swojej Wulgaty: et ne nos inducas in tentationem".

Wulgata zaś była podstawą tłumaczeń na język polski do lat sześćdziesiątych ubiegłego wieku. Słowa „i nie wódź nas na pokuszenie” są dosłownym tłumaczeniem z łaciny (kalką). Popularny przekład Ewangelie i Dzieje Apostolskie dokonany z Wulgaty przez ks. Eugeniusza Dąbrowskiego miał 25 wydań, ostatnie w roku 1974.

Czy Bóg nas kusi? Sformułowanie: „i nie wódź nas na pokuszenie” musi wzbudzić zdumienie, a nawet zgorszenie. Bo jak można przyjąć, że Bóg, nasz dobry Ojciec, który nikogo nie kusi, może nas wprowadzać w pokusę, a więc w bezpośrednie niebezpieczeństwo popełnienia grzechu? ${ }^{4}$. To, że Bóg może dopuścić pokusę, nie oznacza, że On jest twórcą pokus. Wyraża to jasno List św. Jakuba: „Kto doznaje pokusy, niech nie mówi, że Bóg go kusi. Bóg bowiem ani nie podlega pokusie ku złemu, ani też nikogo nie kusi. Każdego wystawia na pokusę i nęci własna pożądliwość" $(1,13)$.

Problem jednak w tym, że niewielu zna te słowa listu, każdy jednak zna na pamięć fragment Ojcze nasz w wersji zaniechanej w przekładach Pisma Świętego: „i nie wódź nas na pokuszenie”. Nie jest to prośba o to, abyśmy nie doznawali pokus, ale byśmy pokusom nie ulegali. Dawny przekład

${ }^{1}$ Por. Ewangelia według św. Mateusza. Wstęp - przekład z oryginału - komentarz, oprac. J. Homerski, Poznań 2004, s. 149-150 (Pismo Święte Nowego Testamentu, 3.1).

${ }^{2}$ Por. przypisy do Łk 11, 4 w: Pismo św. Nowego Testamentu i Psalmy. Najnowszy przekład zjęzyków oryginalnych z komentarzem, oprac. zespół biblistów polskich z inicjatywy Towarzystwa Świętego Pawła, Częstochowa 2005.

${ }^{3}$ J. Drozd, Ojcze nasz - Modlitwa Pańska według współczesnej egzegezy, Katowice 1983, s. 180 (Attende lectioni, 9).

${ }^{4}$ Por. tamże, s. 175. 
trzymający się niewolniczo tekstu oryginalnego prowadzi do nieporozumieńs. Czy kojarzymy sobie tę prośbę z tekstem czytanym na początku wielkiego postu o tym, że Jezusa kusił diabeł? Kuszą zatem: diabeł, własna pożądliwość, złe przykłady, słowa i namowa ze strony bliźnich.

„I nie dopuść, abyśmy ulegli pokusie”

Wątpliwości i zarzuty dotyczące pierwotnego tłumaczenia łacińskiego powstawały od najdawniejszych czasów (np. Tertulian, około 200 roku) i podnoszono je niemal w każdym wieku aż do naszych czasów włącznie. Trafne rozwiązanie wszystkich trudności lingwistycznych i teologicznych występujących przy ustalaniu sensu szóstej prośby Modlitwy Pańskiej podał dopiero J. Heller w roku $1901^{6}$. Komentatorzy szczególnie cytują łączące się z tym tekstem słowa Pana Jezusa w Getsemani zapisane u synoptyków: „Czuwajcie i módlcie się, abyście nie ulegli pokusie”.

Powszechna odnowa biblijna, która wynika m.in. z głodu prawdy szukanej u źródeł, przypada szczególnie na wiek XX. Zaznaczyła się zwiększonym zainteresowaniem tekstami w językach oryginalnych: hebrajskim, aramejskim i greckim i rozwojem teologii biblijnej. Już w XIX wieku powstała teoria gatunków literackich. W wyniku tego pojawiły się na całym świecie nowe katolickie przekłady Pisma Świętego z języków oryginalnych na języki współczesne. W Polsce były nimi i są Biblia Tysiąclecia i inne wspomniane wyżej.

\section{„Nie dopuść, abyśmy ulegli pokusie" w codziennych modlitwach}

Jan Paweł II, przemawiając na audiencji, na której przedstawiono dokument Papieskiej Komisji Biblijnej Interpretacja Biblii w Kościele, powiedział między innymi:,,Jeśli bowiem «słowa Boże [...] upodobniły się do ludzkiego języka» (Dei Verbum, 13), to dlatego, by wszyscy je zrozumieli. Nie powinny one pozostać dalekie, zbyt wysokie dla ciebie, ani zbyt od ciebie «oddalo-

${ }^{5}$ Por. przypisy do Mt 6, 13 w: Pismo Święte Starego i Nowego Testamentu w przekładzie zjęzyków oryginalnych ze wstępami i komentarzami, oprac. zespół pod red. M. Petera i M. Wolniewicza, t. 4: Nowy Testament, Poznań 2004.

${ }^{6}$ Por. J. Drozd, Ojcze nasz - Modlitwa Pańska według współczesnej egzegezy, dz. cyt., s. $176-177$. 
ne». [...] Trzeba zatem stale przekładać myśl biblijną na język współczesny, aby została ona wyrażona w sposób dostosowany do słuchaczy"?.

Kard. Francis Arinze w swoim przesłaniu napisał: ,Język liturgii w obrządku rzymskim opiera się na Biblii. [...] Tłumacze powinni zawsze być uwrażliwieni na biblijnąjakość tekstów liturgicznych, zarówno w sensie bezpośrednim w czytaniach i antyfonach wybieranych do liturgii słowa, jak i w sensie pośrednim, gdy język danej modlitwy przypomina słowa lub wyrażenia z Biblii”.

Korzyści z wprowadzenia do codziennych modlitw czterdziestoletniej prawie formuły w wersji ze słowem „abyśmy” lub bardziej potocznej są wielorakie. Jeśli od dziecka będziemy mieć jasny obraz tego, że zaczęła się i że po wielokroć czeka nas walka z pokusą, i będziemy mieć świadomość tego, że Bóg daje siłę, aby nie ulegać pokusie, to wartość tę zachowamy przez całe życie. Najlepiej zacząć przyswajać sobie tę formułę w nauce codziennego pacierza i kontynuować to w obrzędach mszy świętej, różańcu i innych modlitwach.

Czy wprowadzanie dziecka w świat starych wyrażeń jest potrzebne? Czy będziemy mu tłumaczyć, że to prośba wyrażona w sposób semicki, oraz zachęcać, aby w swoim umyśle przechodziło od wyrażenia semickiego do języka polskiego? To obciąża je niepotrzebnie. U wielu osób takie „przejście” jest zbyt trudne, nie doprowadza do celu, bo słowa, choć wielokroć wymawiane, ale przez dzieci i dorosłych nieuświadomione, ulatują.

O rozpatrzenie prosi się również wersja „i nie daj nam ulec pokusie”. Ma ona tyle samo sylab, co ,i nie wódź nas na pokuszenie”, zatem można zachować rytm odmawiania modlitwy bez zmian. Ma ona pierwowzór językowy w Piśmie Świętym: „Nie daj Boże, bym się miał chlubić z czego innego, jak tylko z krzyża Pana naszego Jezusa Chrystusa" (Ga 6, 14). Słowa te zostały również włączone do liturgii w antyfonie na wejście z uroczystości św. Teresy Benedykty od Krzyża z 9 sierpnia.

${ }^{7}$ Jan Paweł II, Przemówienie na temat interpretacji Biblii w Kościele w: Interpretacja Biblii w Kościele. Dokument Papieskiej Komisji Biblijnej z komentarzem biblistów polskich, przekł. i red. R. Rubinkiewicz, Warszawa 1999, nr 15.

${ }^{8}$ A. Francis, Promowanie kultu Bożego. Przesłanie do Sekretarzy Komisji Liturgicznych Europejskich Konferencji Biskupów, Dobogökö [Węgry], 23 czerwca 2003, „Anamnesis” 9 (2003) nr 4 (35), s. 15-20. 
ModlitwęPańską w Piśmie Świętym poprzedza wezwanie Jezusa: „Wy zatem tak się módlcie” (Mt 6,8) i „Kiedy się modlicie, mówcie” (Łk 11, 2), zaś w tekstach mszalnych poprzedza ją wezwanie: „Pouczeni przez Zbawiciela i posłuszni Jego słowu, ośmielamy się mówić”. W szóstej jednak prośbie Ojcze nasz do tego się nie stosujemy. Drobne bowiem różnice w innych prośbach tej modlitwy wynikają z bardziej lub mniej potocznego języka,jednak to, co mówimy w szóstej prośbie, jest niepoprawne teologicznie i niezgodne z tym, czego uczył Jezus. Można żywić uzasadnioną nadzieję, że „wyprostowanie” modlitwy w codziennym użyciu wzbudzi więcej ufności w pomoc Bożą i siły w opieraniu się pokusom. Łódź

ANTONI SALM

\section{Słowa kluczowe}

Modlitwa Pańska, Ewangelia według św. Mateusza, Ewangelia według św. Łukasza, Eucharystia, przekład

\section{Summary}

"Do not allow us to give into temptation" - from the Bible to the daily liturgy and prayer

As the result of a biblical revival, the Polish text of the petition of the Lord's Prayer in the Bible (Matt 6:13 and Luke 11:4) was changed from "Lead us not into temptation" to "Do not allow us to give into temptation", which was also included in the Lectionary. This text is correct in respect to theology and language, and it is waiting for its place in the Eucharistic liturgy and daily prayer.

\section{Keywords}

Lord's Prayer, Gospel According to Luke; Gospel According to Luke, Eucharist, translation 
